\title{
MODIFICAÇÕES EM CURSO NA ENTRADA DA BARRA DE CANANEIA
}

\author{
Viktor Sadowsky
}

No intuito de prosseguir na pesquisa relacionada com as modificações que se processam na linha costeira e que, em parte, originam formações sedimentares e depósitos diversos na região da entrada da barra de Cananéia - resultantes não só da ação das ondas, mas também das marés — promovemos a aproximação dos primeiros pontos de contrôle e juntamos as linhas esparsas, aí existentes, em um sistema geral que abrangeu tôda a região da barra. Com êsse objetivo, efetuamos extensos trabalhos de ordem topográfica conforme se depreende do "croquis" que acompanha o presente trabalho.

Em primeiro lugar, examinaremos os diversos setores situados no trecho S da Ilha Comprida. A seguir, consideraremos a situação reinante no trecho $\mathrm{N}$ da Ilha do Cardoso, vizinha à Ponta do Perigo ('). Depois disso, nos referiremos ràpidamente aos elementos móveis e ao movimento das marés.

\section{ILHA COMPRIDA $(*)$}

$\mathrm{Na}$ margem $\mathrm{N}$ da entrada da barra, isto é, na extremidade $\mathrm{S}$ da Ilha Comprida, a partir da ponta situada no rumo SW, foi traçada, na direção E, uma linha de observação que passa por tôda a orla que acompanha o canal até o SE. Nessa linha foram aproveitados os pontos de contrôle esparsos, já existentes em virtude de trabalhos anteriores, acrescidos de outros, bem como tôda a linha que já existia na Ponta da Trincheira. Foram tomadas por base três pirâmides geodésicas que se encontram localizadas, respectivamente, na Ponta da Trincheira, na Praia do Meio e na Praia do Pontal ; as pirâmides extremas estando si cuadas em uma linha que mede, aproximadamente, 2.300 metros. Os pontos de contrôle dessa linha acham-se distantes, um do outro, cêrca de 100 metros, com exceção da parte da Ponta da Trincheira, na qual, em virtude de alterações que julgamos conveniente fazer, reduziu a distancia entre os 10 pontos restantes a uma média de 25 metros.

Dadas certas particularidades topográficas da linha costeira e de acôrdo com o grau de atividade exercida pelas águas que nela se encontram, a linha de observação supra citada foi dividida em quatro setores principais.

(1) - Os dados resultantes de observações correspondentes a um eiclo anual, para fins de repre-

sentação gráfica, foram somados, a fim de nos fornecerem as médias correspondentes a cada setor. 
Os dois primeiros incluem, em si, a orla do canal ; os dois seguintes compreendem a parte voltada para o oceano, até o local em que alinha de costa se curva bruscamente para o $\mathrm{N}$.

O primeiro setor possue 10 pontos de contrôle, medindo aproximadamente 270 metros de extensão. Começa na Ponta da Trincheira e termina no início da Praia do Meio. A orla dêsse setor caracteriza-se por uma sólida camada de uma espécie de piçarra, já referida em trabalhos anteriores sôbre

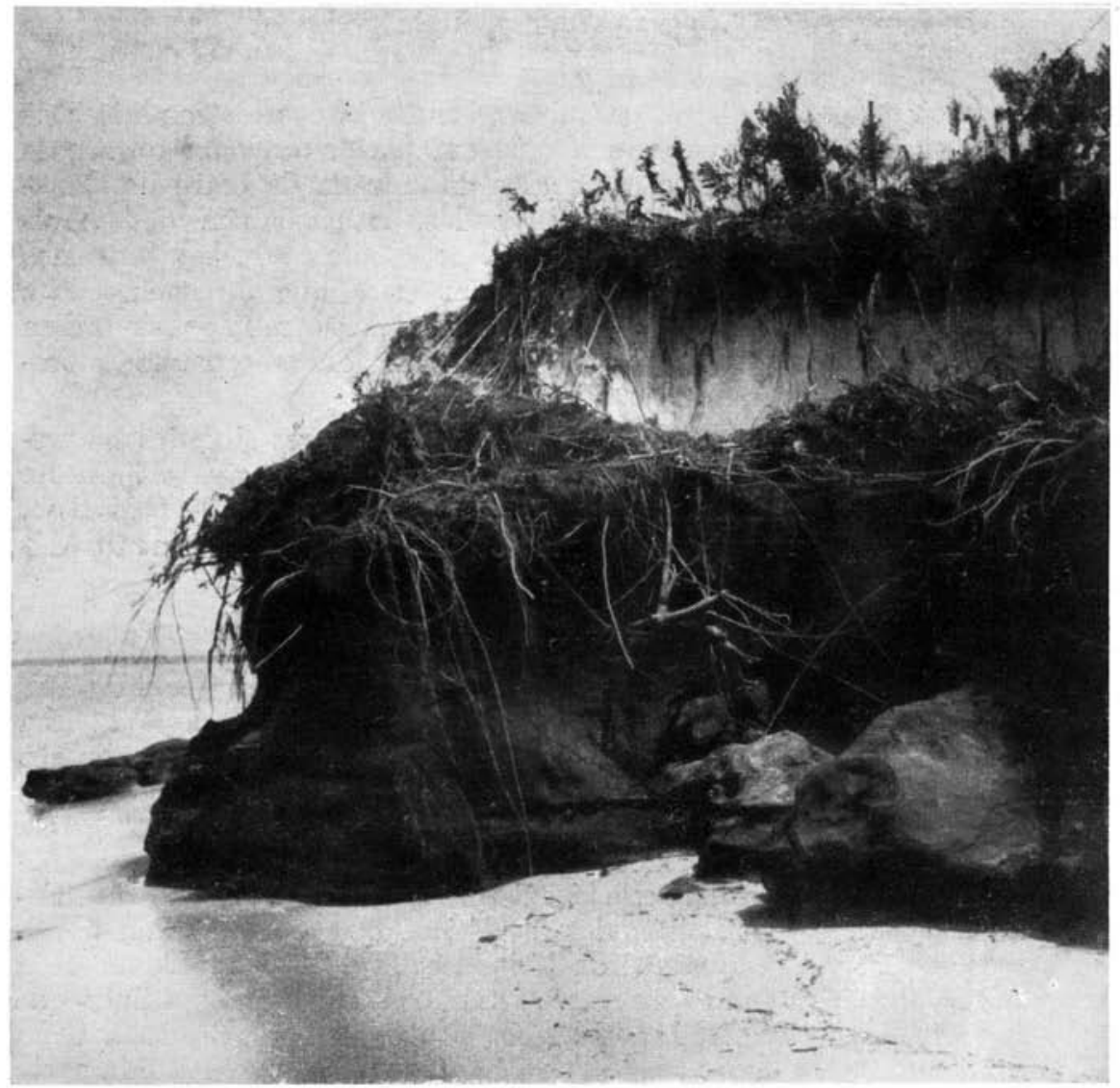

Ilha Comprida - Setor I

a mesma região (Krone 1914, p. 30 ; Besnard 1950, p. 16). Em frente da linha costeira, a uma profundidade que varia de 1 a 5 metros, encontram-se os restos da antiga estrutura da Ponta da Trincheira. As partes emersas que parecem de constituição menos sólida, foram destruidas pela atividade das ondas; a porção imersa é talvez mais resistente e permanece inalterada até cêrca de 150 metros além, na direção do meio do canal, onde in- 
terrompe-se bruscamente e atinge o leito principal que aí alcança cêrca de 21 metros de profundidade. Assim sendo, poder-se-ia explicar o fenômeno do desvio da corrente principal que, por ocasião da maré montante, vinda de ENE, é regeitada para SW. As águas superficiais dessa corrente, já por fôrça de inércia continuam a avançar na direção WNW, aumentando a amplitude das vagas que atacam a barranca de abrasão da ponta da Trincheira. Esse setor, sobretudo durante a maré montante, acha-se submetido

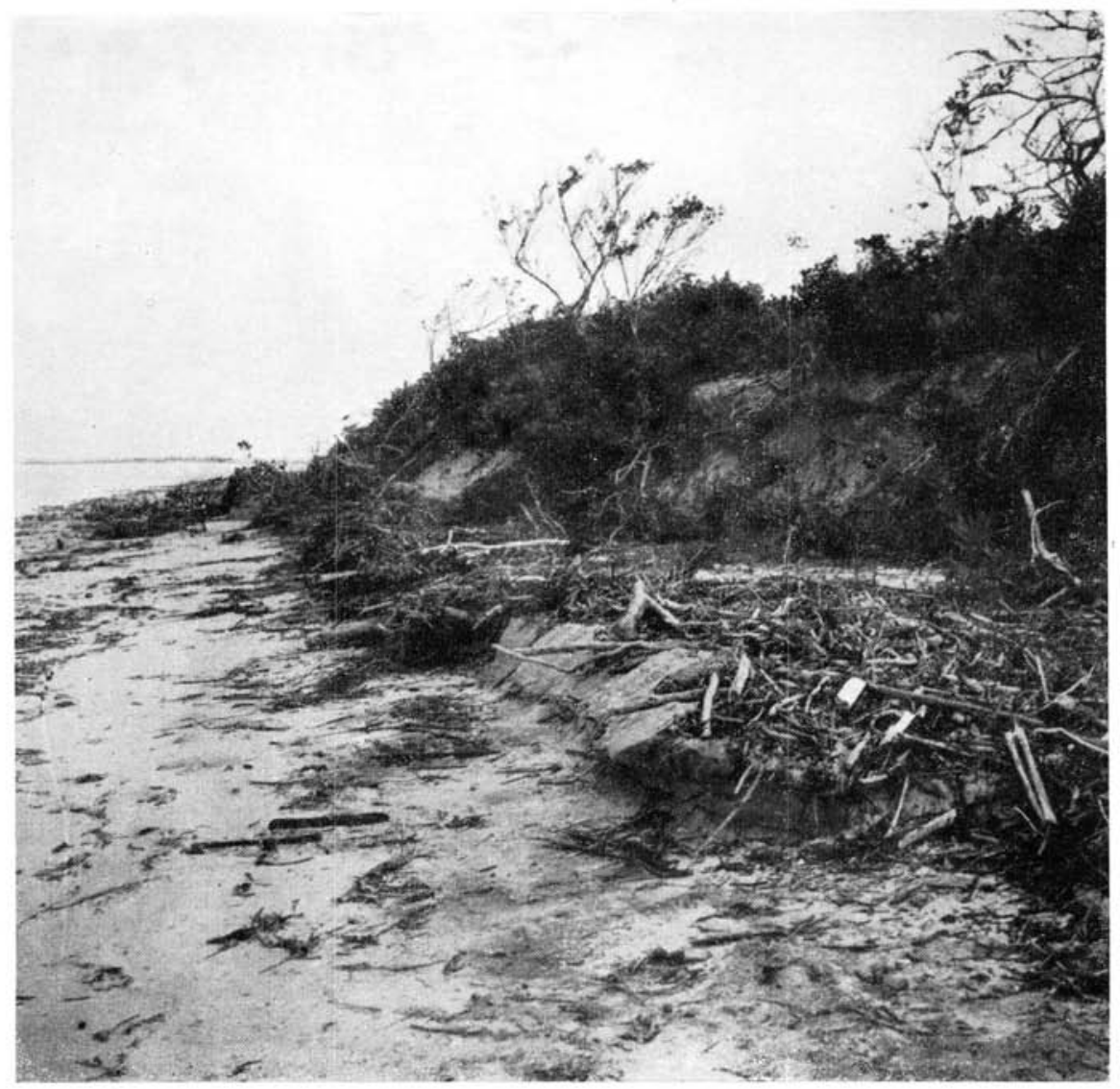

Ilha Comprida - Setor II

sistemàticamente a uma ação erosiva, embora lenta, dada a constituição da sua margem. Por ocasião da vasante, a corrente proveniente do Mar Pequeno junta-se quase em ângulo reto à que vem da Baía de Trapandé, protegendo assim da destruição, a margem do primeiro setor.

O segundo setor comporta em si a praia do canal (cêrca de 700 metros) e tem 7 pontos de contrôle. A altura da margem varia de 1 a 2 metros, pos- 
suindo vegetação geralmente baixa, porém densa. A margem costeira dêsse setor acha-se protegida contra a ação das águas, devido à inclinação suave da praia. De acôrdo com as observações que efetuamos, esta praia está sofrendo alterações temporárias. Mas, em relação a todo o período observado, ela se manteve em relativo equilíbrio.

O terceiro setor, situado na margem externa do canal, tem 400 metros de extensão e comporta 5 pontos de contrôle. A encosta dêsse setor exibe em

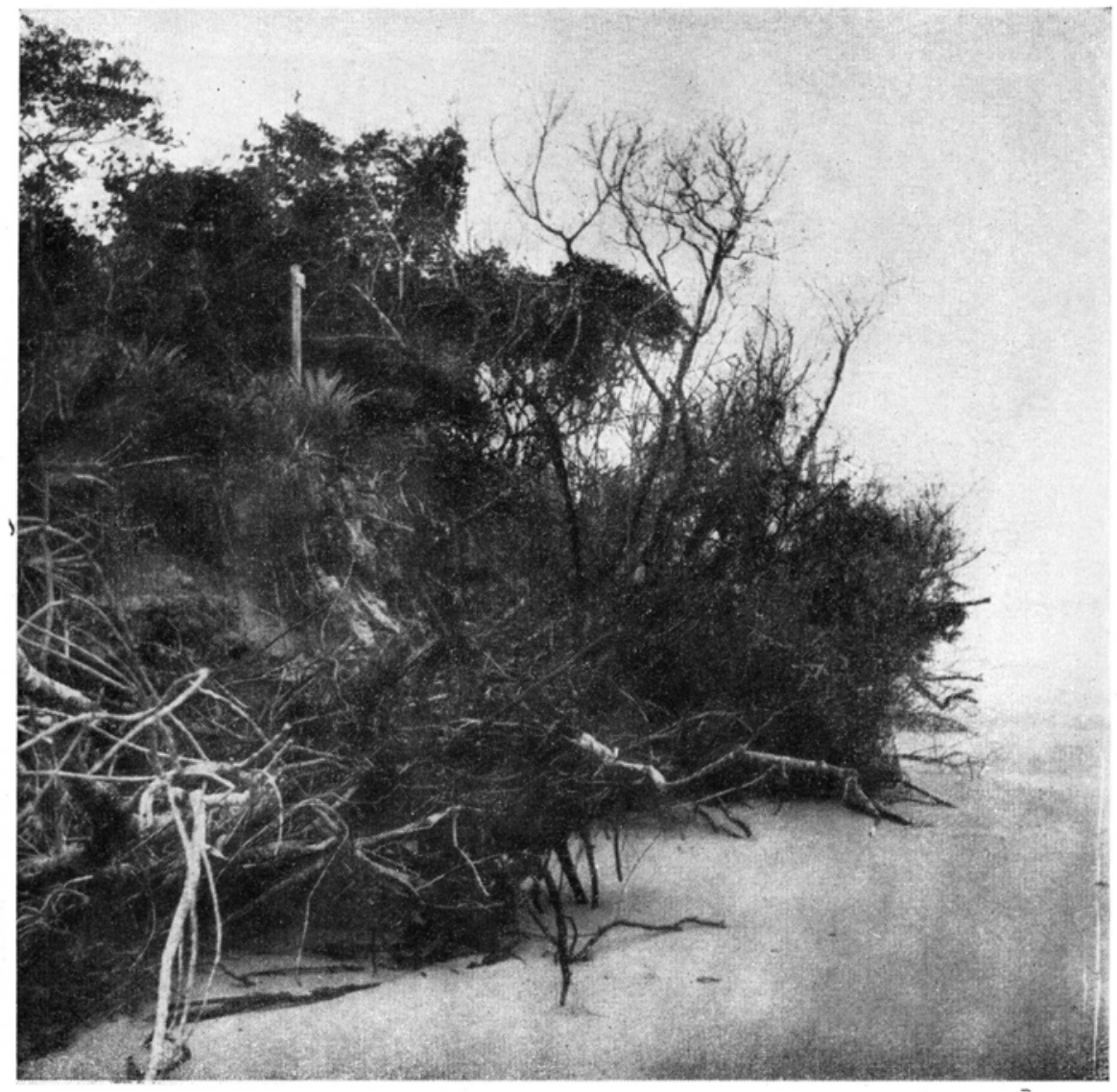

Ilha Comprida - Setor III

certos pontos, 3 metros de altura, sendo constituida por terra vegetal, na superfície, areia de praia e piçarra, na base. Sôbre uma larga camada de 25 centímetros de espessura, cresce um mato denso e baixo onde se encontram árvores esparsas de porte mais elevado. As raizes dispõem-se em densa rêde, formando armadura resistente para o solo vegetal. A linha costeira possue uma reentrância formada em consequência da ação da arrebentação 
por ocasião da atividade de ventos dominantes do quadrante S. Justamente nêsse setor, á margem da Ilha Comprida fica localizada fora da ação protetora oferecida pela margem oposta do canal, isto é, do seu ponto extremo (Ponta do Perigo na Ilha do Cardoso). Este setor encontra-se fortemente submetido à atividade e desgaste, sofrendo modificações quer na montante, quer na vasante. Sòmente a constituição compacta da margem e a vegatação desenvolvida aí existente, proteje êsse setor contra desgastes

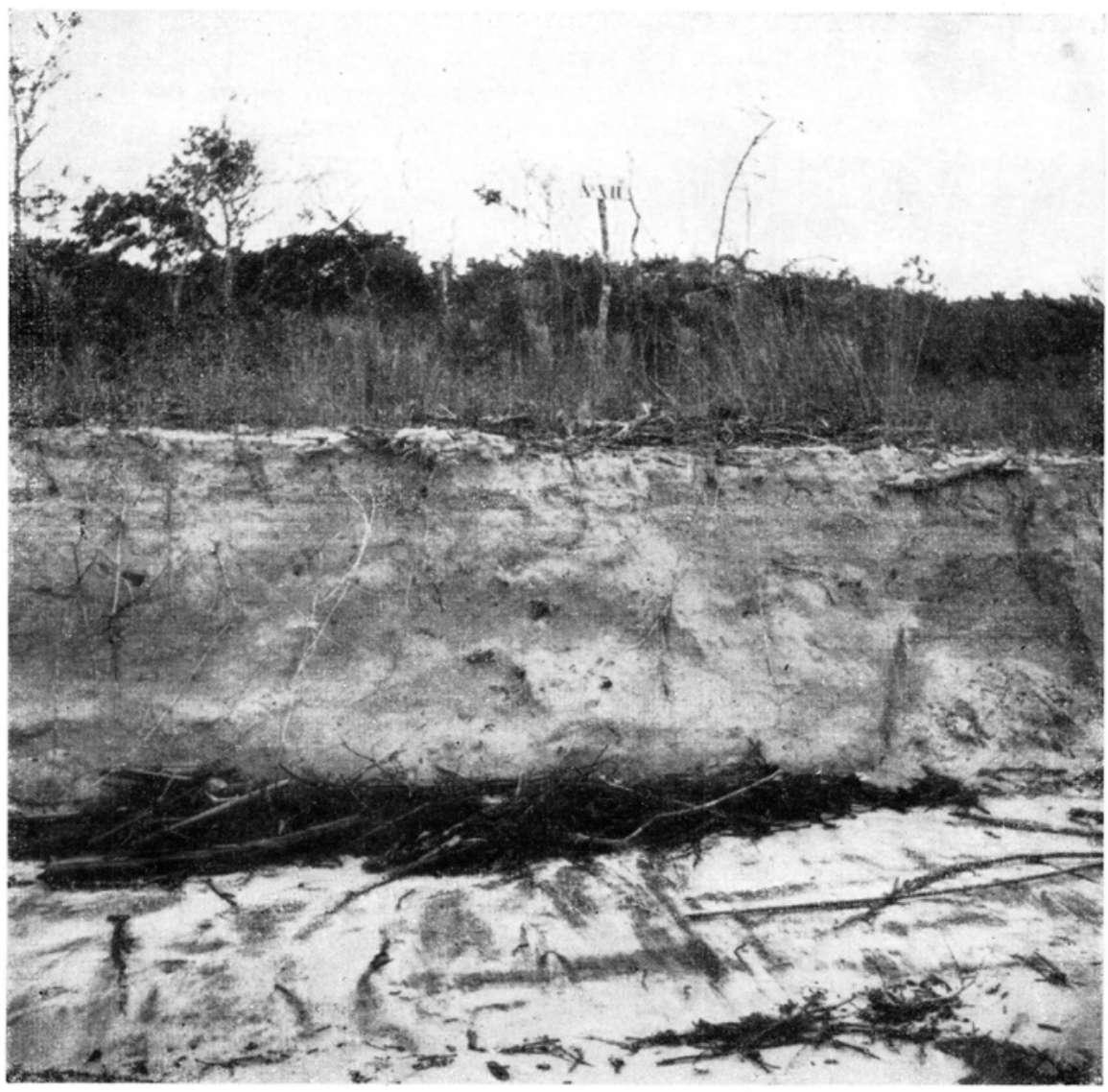

Ilha Comprida - Setor IV

ainda maiores. Na praia da reentrância a que já aludimos, encontram-se pequenos pedregulhos de quartzito. Infelizmente ainda não pudemos atinar com a fonte de origem do material quartzitico.

O quarto setor cobre uma linha costeira com extensão de 800 metros, estando nêle figurados nove pontos de contrôle. Representa a continuação do trecho costeiro situado já fora do canal. A partir do terceiro setor, o 
aspecto do terreno se modifica notàvelmente. Acha-se representado por dunas interiores (Rawitscher, 1944, p. 21), por antedunas e, a seguir, extensa praia. Sua margem é composta de dunas baixas arenosas, de formação recente, cobertas por uma vegetação pioneira, muito pouco desenvolvida. A altura da margem vai diminuindo aos poucos e, a partir do ponto de contrôle n. 20, transforma-se o setor numa vasta praia em cuja continuação se formam grandes bancos de areia, situados na parte $\mathrm{N}$ da barra. Dotado de praias amplas, o setor não se encontra submetido a modificações por ocasião das marés baixas; ao contrário, durante as grandes marés, as ondas e as correntes minam e lavam a areia das dunas. Torna-se interessante esclarecer que durante o desgaste da margem, numa profundidade de cêrca de 1,20 metros, podem ser observadas formações de origem mais antiga, onde, eventualmente se deparam com restos muito bem conservados de árvores e outros detritos de aspecto muito recente, recobertas por camadas de areia. O ponto extremo de contrôle (n. 20), situado na Praia do Pontal, evidenciou atividade contínua, provocando uma alternância de depósitos móveis que aumentam ou diminuem sobretudo de acôrdo com o estado do tempo e do mar.

Se confrontarmos o contôrno atual da linha costeira com o do Mapa da Marinha correspondente ao ano de 1939 (Mapa n. 1703), constataremos que houve um forte acréscimo da margem em direção ao alto mar, nessa região da ilha, o que nos permite supor que o desgaste em si, representa um fenômeno relativamente recente.

\section{ILHA DO CARDOSO}

Na margem $\mathrm{S}$ da entrada da barra, em plena Ilha do Cardoso, depois de terem sido erigidas 3 pirâmides geodésicas, foram abertas duas picadas de penetração : uma com 900 metros, seguindo o curso natural da margem do canal, tem seu início na pirâmide n. 1, terminando em idêntico marco colocado na Ponta do Perigo. A segunda, partindo dêste ponto, faz um ângulo de $90^{\circ}$ com a primeira, segue na direção $\mathrm{S}$ e atinge após $1.900 \mathrm{me}-$ tros, a terceira pirâmide, continuando a rota até a desembocadura de um pequeno riacho $\left({ }^{2}\right)$. A segunda picada, com extensão de 2.700 metros, achase ligada na sua extremidade com as regiões vizinhas : Ponta de Itacurussá e Ilha Nova, as quais estão sendo observadas pelo Prof. W. Besnard. Sôbre essas linhas, de 100 em 100 metros, foram levantadas perpendiculares em direção ao mar. A linha de observação de acôrdo com a constituição da margem e o grau de atividade exercida pelas águas, foi repartida em cinco setores : o $1 .^{\circ}$ e o $2 .^{\circ}$ setor englobam a margem S da entrada da região lagunar ; o $3 .^{\circ}, 4 .^{\circ}$ e $5 .^{\circ}$ compreendem a margem da Ilha do Cardoso, que faz face para o oceano.

O $1 .^{\circ}$ setor inicia-se na pirâmide 1 , com o comprimento de 600 metros, nêle figurando 6 pontos de contrôle. A margem dêsse setor é arenosa e

(2) - Trata-se do Rio do Barco, assim chamado devido ao naufrágio, já antigo, de um barco, cujos destroços atualmente se encontram aproximadamente a 800 metros no interior da embocadura do rio.

(*) - Vide "crog̣uis." 
baixa, (cêrca de 1 metro de altura) ; a constituição do solo é arenosa e móvel, sendo sua vegetação provàvelmente de origem recente. Êsse setor, durante o período anual em que foi submetido à observação, acusou algumas modificações mensais, não apresentando alterações dignas de nota em relação à linha costeira. As medidas obtidas quanto às profundidades das águas dessa região, ou seja, na frente da linha costeira, indicaram que nela se processa lento acréscimo de sedimentos arenosos.

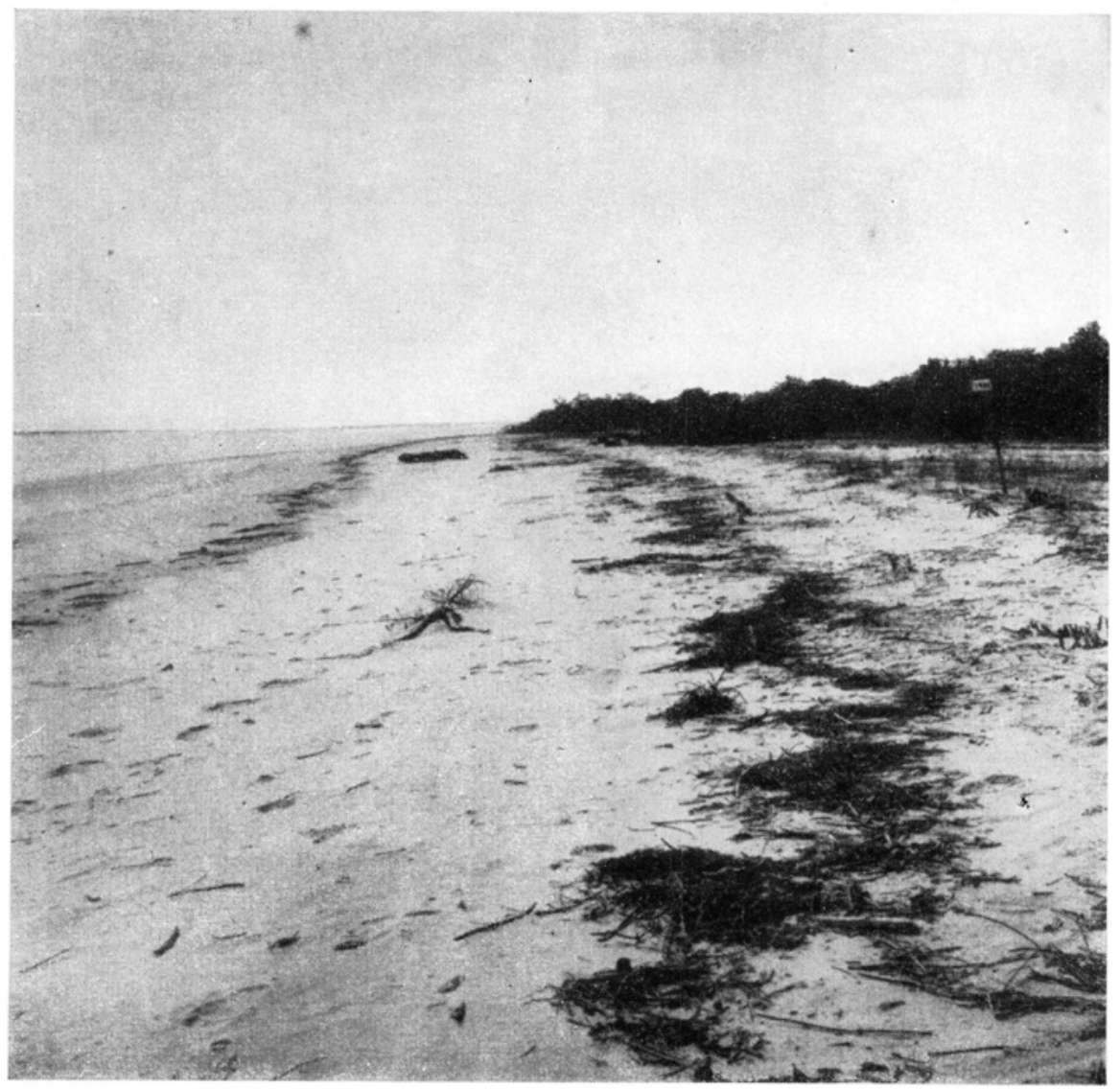

Itha do Cardoso - Setor I

O 2. ${ }^{\circ}$ setor possue 300 metros de extensão, com 3 pontos de contrôle, terminando na pirâmide erguida na Ponta do Perigo. A orla costeira dêsse setor é constituida por um pontal arenoso de formação recente, apenas recoberto em parte por vegetação rasteira, estando êsse ponto fora da ação de fortes correntes, bem como ao abrigo da influência direta das tempestades do quadrante S. À vista disso, observa-se ao longo de todo o setor, 
grande acréscimo de novos sedimentos arenosos, não só emersos como imersos. Na praia do setor considerado, em virtude de rodamoinhos ocasionados pelo movimento das águas costeiras, encontram-se frequentemente restos de árvores arrancadas e transportadas das margens atacadas das costas SE da Ilha do Cardoso. As provas e resultados constantes da parte final do presente trabalho, esclarecem êsse fenômeno.

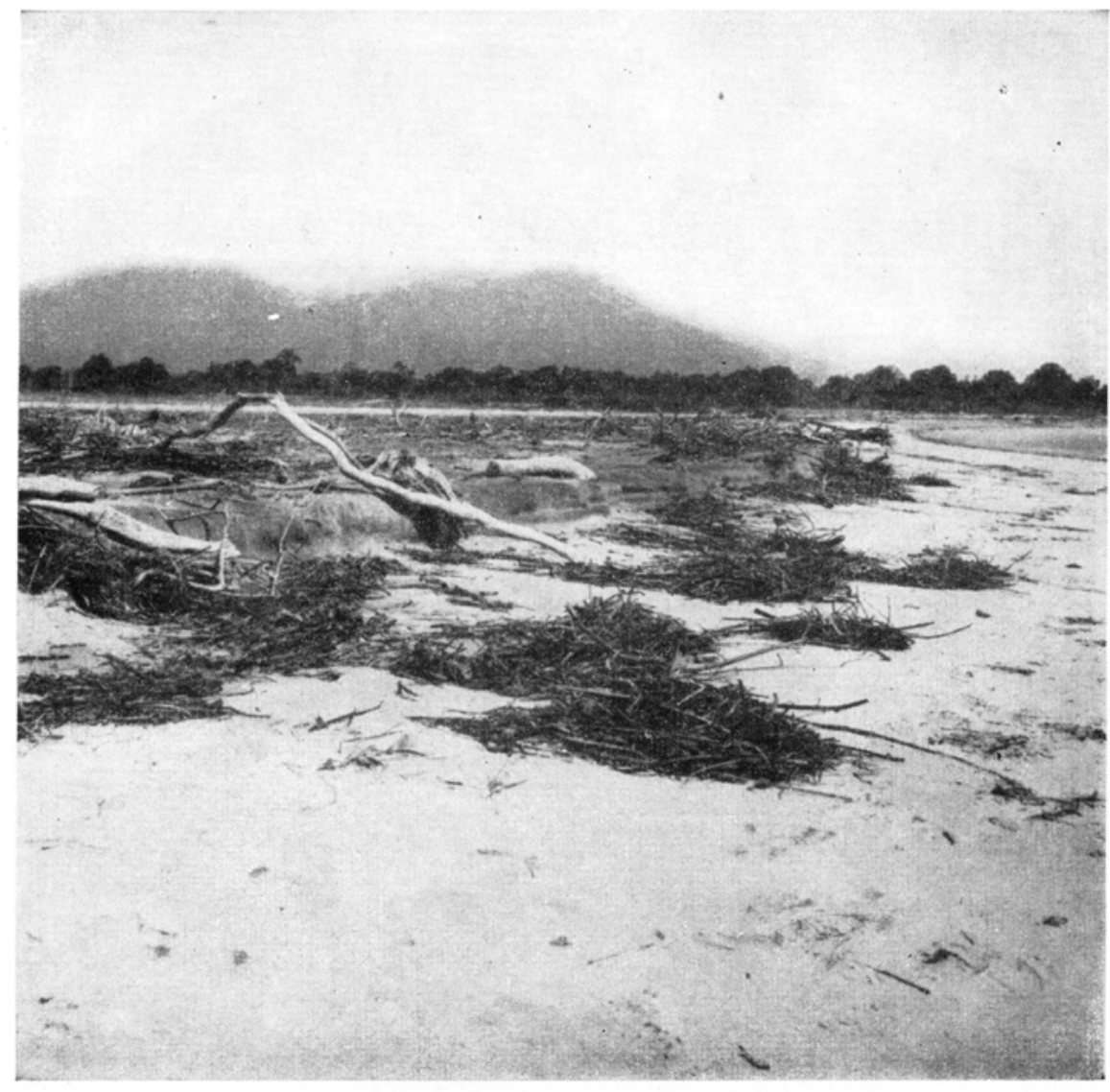

Ilha do Cardoso - Setor Il

O $3 .^{\circ}$ setor tem seu início na pirâmide da Ponta do Perigo e ruma na direção S, cobrindo uma distância de 1.000 metros. Sua margem caracteriza-se por um pontal de areia de aproximadamente 200 metros de comprimento, desprovido de vegetação, atraz do qual levanta-se uma encosta mais sólida e antiga que constitue a margem pròpriamente dita, de cêrca de 1 metro acima do nível da praia, dotada de uma camada de solo vegetal de 15 centímetros de espessura, provida de farta vegetação arbustiva apresentando até pequenas árvores de porte regular, cujas raizes formam um trançado 
resistente. Em virtude da constituição da restinga, e da sua situação topográfica da Ponta do Perigo, explicam-se os números elevados registrados em relação à atividade do desgaste observado no início dêsse setor. A intensidade da erosão, que atinge o seu climax na Ponta do Perigo, diminui ảos poucos na direção S. Neste setor a observação dos efeitos da erosão demonstrou uma tendência decisiva de avanço para o $\mathrm{N}$ dos materiais de desgaste, contornando o próprio cabo, com passagem pelo interior do canal. $\mathrm{Na}$

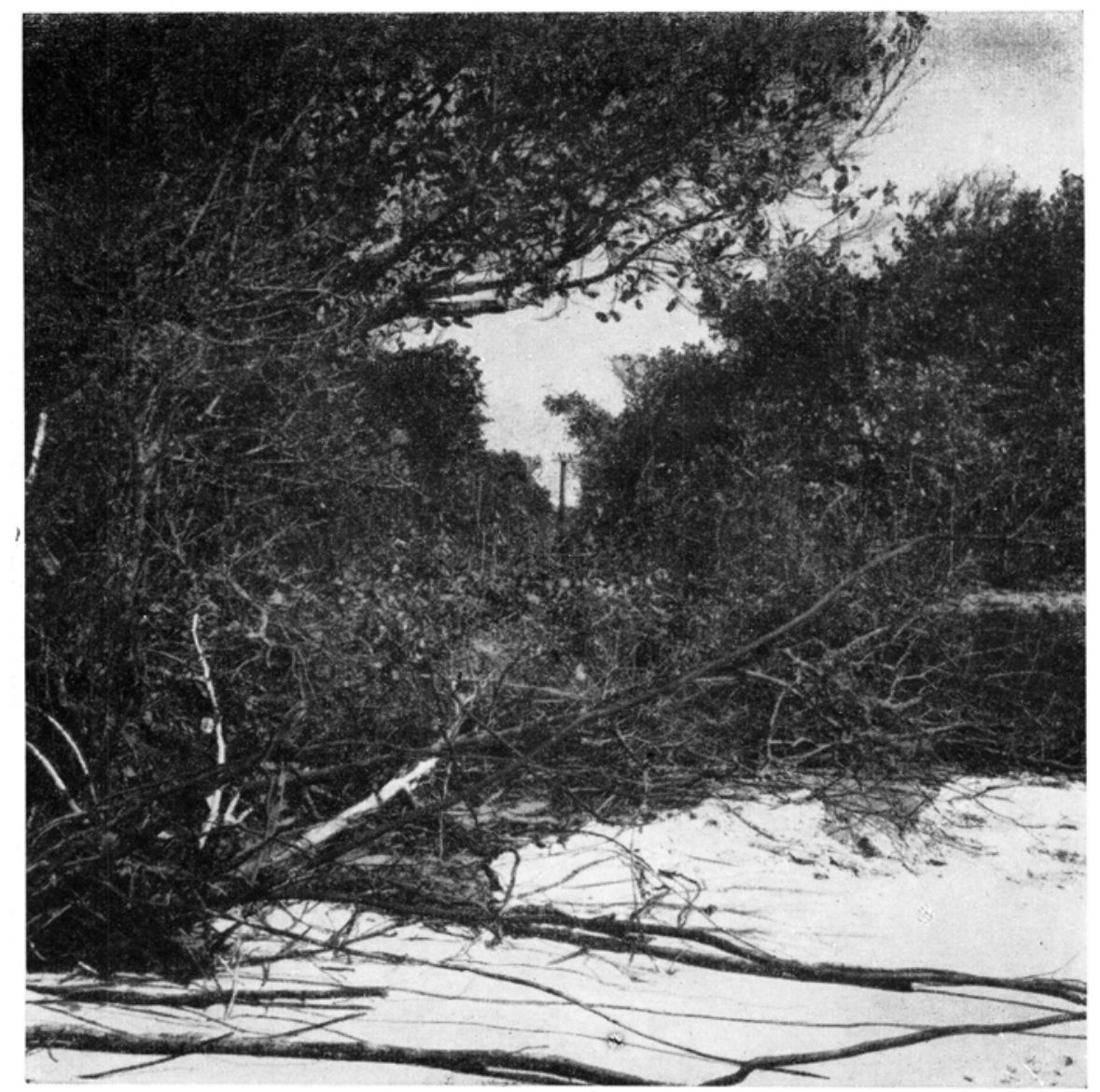

Ilha do Cardoso - Setor III

praia da Ponta do Perigo encontram-se, com frequência, pequenos seixos marinhos, oriundos provávelmente de formações rochosas típicas da Ponta de Itacurussá (filitos proterozóicos da série São Roque), situada, aproximadamente, a uns $5 \mathrm{~km}$ mais ao $\mathrm{S}$. Tal particularidade poderia talvez servir de prova para demonstrar a tendência que tem a água de efetuar o transporte de depósitos nessa direção. Parece-nos oportuno esclarecer aqui o fato de que uma ilha 
arenosa que se formou nas proximidades da Ponta de Itacurussá, não exibe qualquer vestígio de existência de tais fragmentos de rocha. Se compararmos a atual situação da linha costeira com a figurada no mapa da Marinha correspondente a 1939 (Mapa n. 1703) verificaremos que existe, hoje em dia, grande diferença. A linha costeira foi desviada para a frente, no rumo W em cêrca de $400 \mathrm{~m}$ em relação à atual Ponta do Perigo que, no antigo mapa, encontrar-se-ía dentro d'agua, no Canal. Baseando-nos nessas

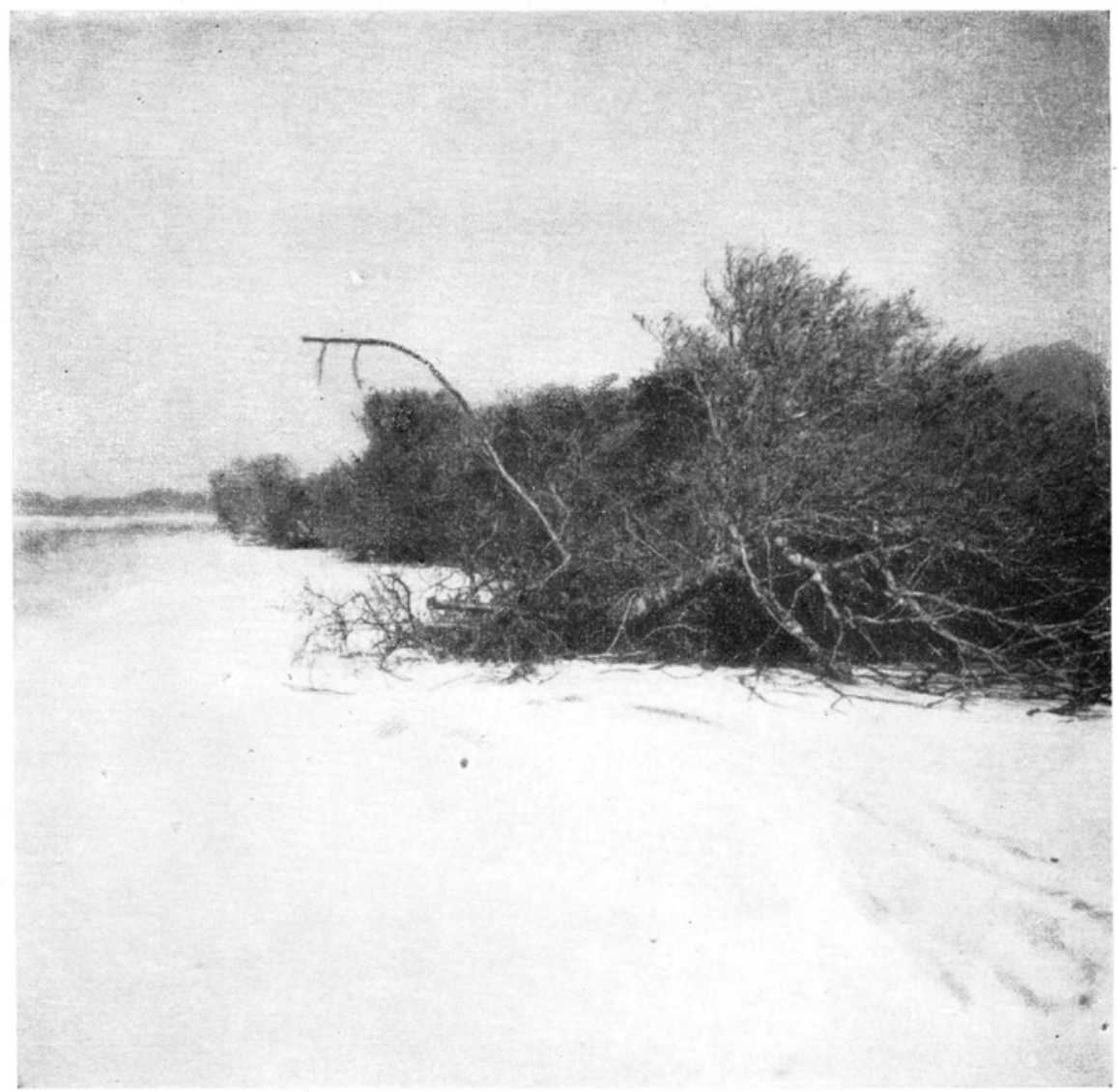

Illa do Cardoso - Setor IV

comparações supômos poder concluir que os resultados anuais da erosão seriam decorrentes da ação desgastante do mar, no transcurso de vários anos.

O $4 .^{\circ}$ setor cobre uma distância de $1.000 \mathrm{~m}$ e tem 10 pontos de contrôle. Representa a continuação do terceiro setor e termina na saída da linha Sul de observação, na própria margem da Ilha que, neste lugar, en- 
curva-se para SW. A margem dêsse setor, que possue cêrca de 1m de altura, caracteriza-se pelo fato de apresentar vegetação muito desenvolvida em sua porção inicial, diminuindo pouco a pouco a sua exuberância até se transformar em vegetação pioneira que vai recobrindo dunas arenosas de formação visivelmente recente. Como acontece em relação ao setor anteriormente referido, aqui, a intensidade do desgaste é maior no começo e menor no último ponto de contrôle.

O $5 .^{\circ}$ setor desdobra-se ao longo de 700 metros da margem, tendo 7 pontos de contrôle. A linha costeira dêsse setor apresenta formações arenosas que têm o aspecto de dunas baixas, cobertas de vegetação muito rala de gramineas psamófitas. Em frente à linha costeira estende-se uma larga faixa de praia raramente coberta pelas águas durante a préamar. Êsse setor acha-se ainda mais abrigado pela nova formação de uma grande corôa que já tem o aspecto de ilha, situada paralelamente à costeira a uma distância de cêrca de 300 metros. Este quinto setor não sofreu propriamente modificação nenhuma no decurso de um ano. A praia e os bancos costeiros demonstram uma tendência para crescer e avançar em direção à "Ilha Nova".

\section{BANCOS DE AREIA}

Em consequência de dificuldades de ordem técnica, o crescimento dos bancos de areia só foi anotado esporadicamente e apenas em alguns setores. As medidas foram tomadas durante as marés de quadratura ou meias-marés. A profundidade da água sôbre os bancos observados oscilou entre 50 e $80 \mathrm{~cm}$.

\section{ILHA DO CARDOSO}

\begin{tabular}{c|c|c|c|c}
\hline Setor & Mês & $\begin{array}{c}\text { Comprimento médio cons- } \\
\text { tatado nos bancos }\end{array}$ & Mês & $\begin{array}{c}\text { Modificação } \\
\text { constatada }\end{array}$ \\
\hline 2, NP 2 & Out. & 21 metros & Abril & $+54=75 \mathrm{~m}$ \\
5, NP 22 & Dez. & 100 metros & Abril & $+30=130 \mathrm{~m}$ \\
5, NP 27 & Dez. & 125 metros & Abril & $+70=195 \mathrm{~m}$ \\
\hline
\end{tabular}

Foi feita uma série de experiências, cujos resultados serão apreciados a seguir, para verificar a direção em que se está efetuando o transporte dos produtos de desgaste da margem oriental da Ilha do Cardoso. Empregaram-se flutuadores dispostos a distâncias de 20, 40 e 60 metros da praia, em frente ao ponto de contrôle n. ${ }^{\circ} 1$, do terceiro setor. Tôdas as experiência foram feitas com bom tempo, soprando vento fraco, predominantemente S. Essas experiências foram efetuadas tanto por ocasião da enchente com da vasante.

Durante a enchente os flutuadores colocados nas distâncias de 20 e 40 metros, contornaram a Ponta do Perigo, tendo sido jogados à praia pelas 
ondas, no setor 2 , próximo ao ponto de contrôle n. ${ }^{\circ} 1$. O terceiro grupo de flutuadores colocado na distância de 60 metros, seguiu mais ou menos o mesmo caminho, porém tendo o seu ponto de partida mais distante da praia, em sua maioria encalhou num banco de areia situado em frente ao ponto de contrôle $n .^{\circ} 2$, do segundo setor. Atraido depois pela atividade das águas de enchente, continuou a sua marcha pelo canal a dentro. Aproximando-se da Ponta da Trincheira, na Ilha Comprida, tomou o rumo SW e juntando-se à corrente predominante do Canal, ingressou na baía de Trapandé, embora alguns flutuadores houvessem encalhado no início dos bancos de areia do Baixío Grande. No fim da vasante, vimos várias vezes os flutuadores aparecerem nas praias dos setores 3 e 4 da Ilha Comprida.

Por ocasião da vasante, os primeiros flutuadores colocados a $20 \mathrm{me}-$ tros de distância foram, em sua maioria, devolvidos à praia, não ultrapassando, via de regra, a Ponta do Perigo. Do segundo grupo de flutuadores, a maioria, que havia sido colocada a uma distância de 40 metros, circundou a Ponta do Perigo e acabou encalhando nas praias do segundo setor, entre os pontos de contrôle 1 e 3 . Os flutuadores do terceiro grupo, colocados a 60 metros de distância, penetraram no canal, porém foram envolvidos pelos movimentos de rodamoinho e após atingirem um ponto distante mais ou menos 150 metros da margem dêste acompanharam o movimento da vasante, deslisando no rumo NE. Uma parte dêstes flutuadores foi têr às praias da Ponta de Fóra, na Ilha Comprida.

Baseando-nos em algumas sondagens efetuadas próximo às margens desta região não constatamos nenhuma alteração importante para mais ou para menos nos bancos de areia, no interior da entrada da região lagunar, exceção feita dos casos já citados. Suponhamos que alguns mil metros cúbicos de areia tenham sido transportados pelas águas depois destas terem minado e lavado as praias ; todo êsse material está sendo transportado pelas águas costeiras com o auxílio da maré enchente, vindo acumular-se dentro. do canal. A partir dêssa fase perdemos o contacto com êsse material, não nos sendo possivel, no estado atual da nossa pesquisa, dizer com segurança qual o seu destino. Realmente, se, por um lado, deparamos com um baixío extenso (o Baixío Grande) situado em frente à entrada da Barra, próximo à Ilha de Cananéia, cuja margem externa é constituida por areia muito fina e quase pura, por outro, torna-se difícil explicar a ocorrência de enorme quantidade de areia acumulada na parte $\mathrm{N}$ da Barra, em continuação ao Pontal de Fóra, na Ilha Comprida. Outros componentes da equipe do Instituto Oceanográfico estão fazendo o estudo dos movimentos dos produtos de erosão, das correntes, do sublevamento do fundo e a granulação das areias, devendo o resultado dessas pesquisas ser publicado oportunamente neste Boletim.

\section{AS MARES}

Por vários motivos não foi possível, ainda, pôr em funcionamento o marégrafo da Base de Pesquisas de Cananéia e nem obter dados rigorosos quanto ao movimento das marés. Limitamo-nos, por conseguinte, a assinalar 
sòmente a amplitude das marés observada na régua instalada para êsse fim. De um modo geral, examinando as curvas observadas dentro dos recursos ao nosso alcance, acreditamos que os movimentos das marés aproximam-se bastante aos calculados pelas Tábuas de Marés, do Observatório Nacional, para o porto de Paranaguá. A respeito do assunto, julgamos conveniente recordar as palavras de Belfort Vieira (1942, p. 76) quando diz: "Em Paranaguá onde, como já dissemos, há a influência das harmônicas e dos fatores geográficos e meteorológicos, produzem-se as marés mais complicadas do Brasil".

\section{GRĀFICOS}

As observações foram conduzidas metòdicamente mês por mês, baseadas no sistema dos pontos de contrôle. Concomitantemente procedeu-se ao registo da amplitude das marés, como já foi dito, superiores a $1,60 \mathrm{~m}$, de acôrdo com a régua de marés instalada na nossa Base de Pesquisas. Os resultados obtidos durante um ano, constam separadamente e para cada linha de observação, em gráfico especial, onde se indica o setor respectivo, os números dos pontos de contrôle e o mês em que foi feita a observação. Além disso, para maior clareza, organizamos ainda quatro gráficos, dois dos quais são análogos para cada linha de observação.

Os gráficos I e II, referem-se às modificações das margens, registadas no decorrer de um ano, em pontos de contrôle separados. Alguns dêles, erigidos posteriormente, não contêm dados de um ciclo total mas sòmente de 2, 4 ou 6 mêses, pelo que os registos respectivos aparecem assinalados de forma diferente para distingui-los dos demais. O gráfico II (Ilha do Cardoso), exibe duas linhas retas indicando o desgaste a partir da piramide erigida na Ponta do Perigo (Ponto n. " "O"), significando que daí em diante foram efetuadas as observações em duas direções: $\mathrm{N}$ e E.

Os gráficos III e IV, representam as observações mensais efetuadas e referentes à ação dinâmica das águas, nas modificações dos setores separados da linha costeira das duas margens da entrada. Como elemento elucidativo, anotou-se também a correlação existente entre a rapidez em que se estão produzindo as modificações das margens e o número de marés de amplitude acima de $1,60 \mathrm{~m}$, registadas durante os mêses de observação.

No texto do presente relato, incluimos uma documentação fotográfica com aspectos do período em que se levou a cabo a investigação, focalizando as margens das duas ilhas que formam a entrada de Cananéia.

Para melhor orientação dos trabalhos organisamos o "croquis" anexo, no qual se vê a exata situação da região tal como ela se apresentava no dia 1 de maio de 1953. Esse "croquis" evidencia as enormes modificações que se operaram nas margens do canal de Cananéia, desde o ano de 1939, data da publicação do mapa da Marinha Nacional (Porto de Cananéia, levantamento efetuado pela Diretoria de Hidrografia e Navegação, em 1938. Mapa n. ${ }^{\circ}$ 1703). As faixas demarcadas no "croquis", por meio de uma linha pontilhada, ao longo das margens, representam as praias atuais. As medidas de profundidade, dêle constante, foram tomadas durante a maré de qua- 
dratura. Na região SE figura o contôrno da parte de uma ilha arenosa que se está formando, a que se deu a denominação de "Ilha Nova". Entre essa ilha em formação e a margem da Ilha do Cardoso, encontra-se a parte já muito obstruida que representa a porção $\mathrm{N}$ do antigo "canal do Sul" da Barra.

EXPRESSÕES GRÁFICAS DO DESGASTE NOS DIVERSOS SETÔRES

Gráfico I - Desgaste, em metros, na margem da Ilha Comprida.

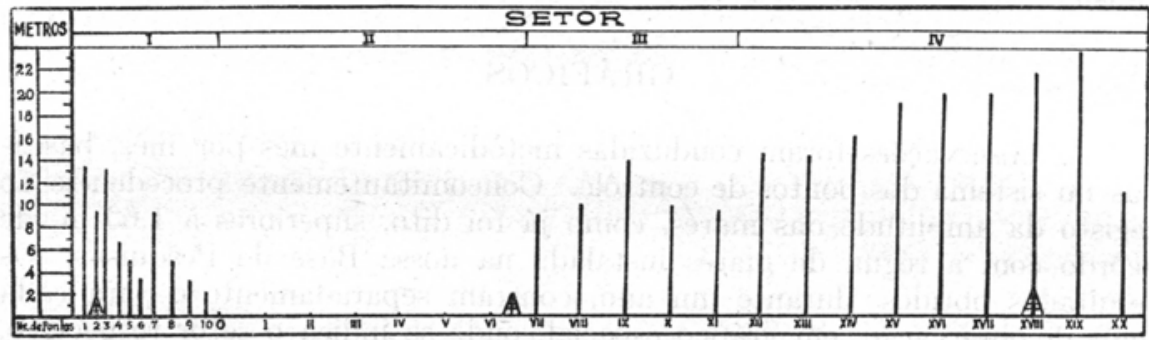

Gráfico II - Modificações, em metros, das margens da Ilha do Cardoso.

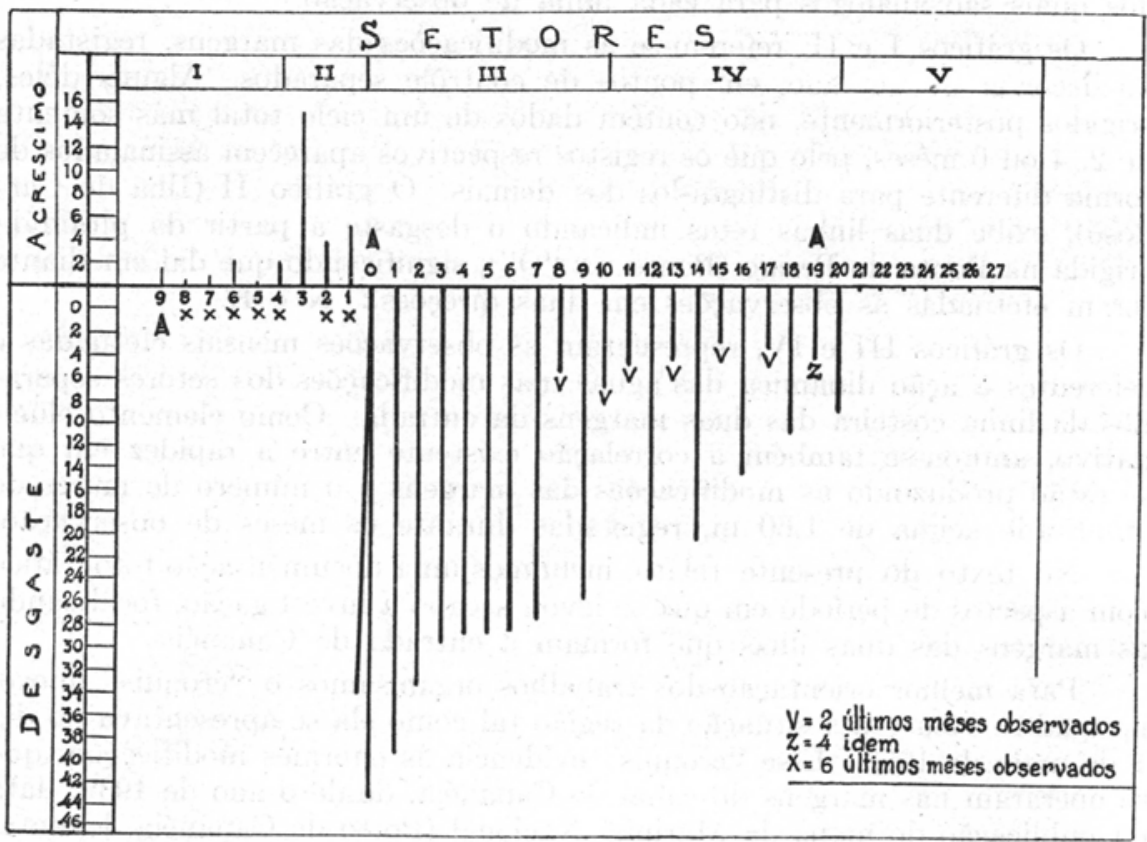

Nota: Os setôres estão marcados em números romanos e os pontos de contrôle em algarismos arábicos.

As cotas batimétricas da Entrada da Barra são expressas em metros e foram tomadas segundo o nível da maré média (22-4-1953). 
Gráfico III - Modificações mensais em eada setor

\begin{tabular}{|l|l|l|l|l|l|l|l|l|l|l|l|}
\hline & V VI & VII & VIII & IX & X & XI & XII & I & II & III & IV \\
\hline & & & & & & & & & & & \\
\hline & & & & & & & & & & & \\
\hline & & & & & & & & & & & $\vdots$ \\
\hline \\
\hline
\end{tabular}

I - Margem do canal, na região da Ponta da Trincheira

II - Continuação da margem do canal, na miesma região

III - Parte da margem do canal de entrada

IV - Praia de Fora 
Gráfico IV - Modificações mensais em eada setor.

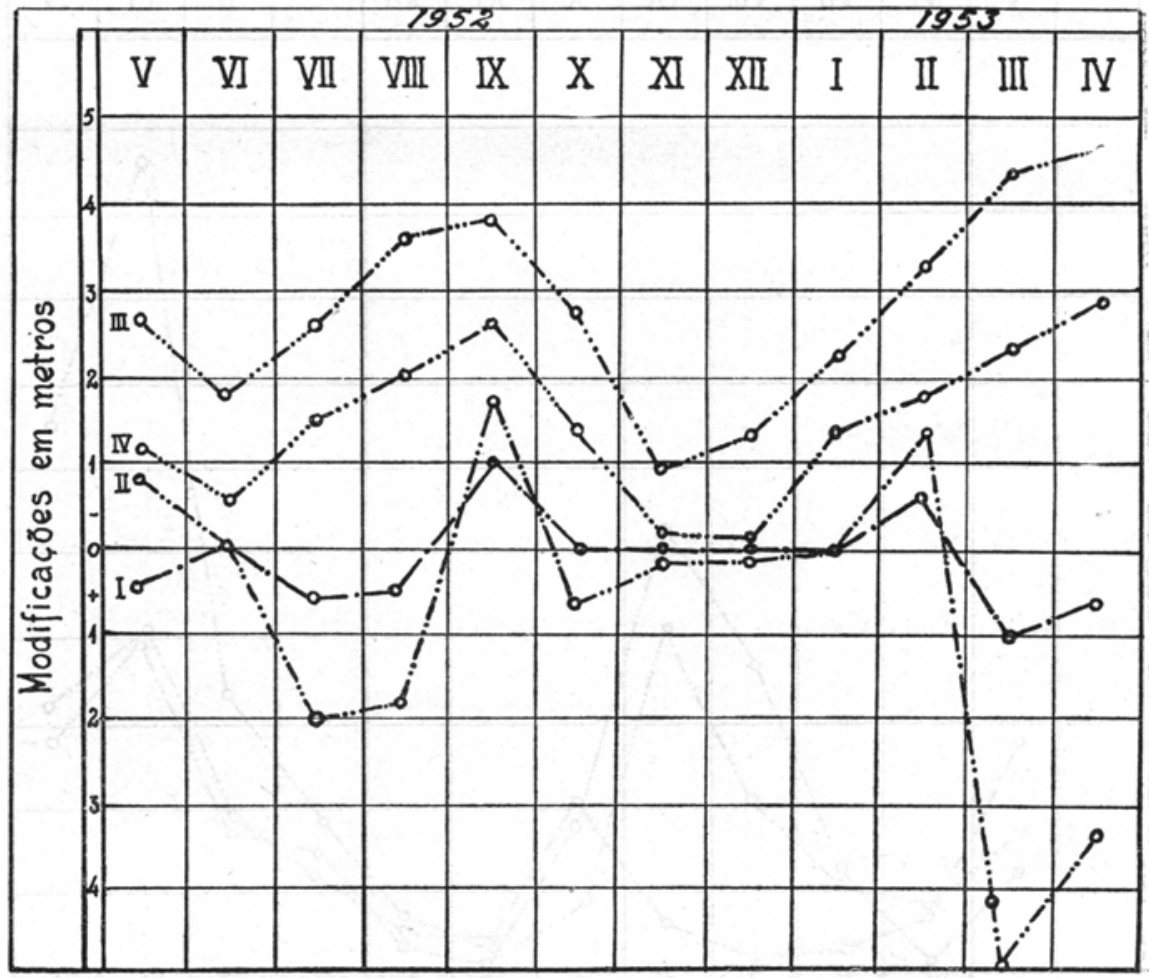

I - Margem do canal de entrada de Cananéia.

II - Continuação da margem do mesmo canal.

III - Praia de Fora.

IV - Continuação da Praia de Fora. 
Gráfico V - Número de marés de amplitude acima de $1,60 \mathrm{~m}$ registadas durante os mêses de observação.

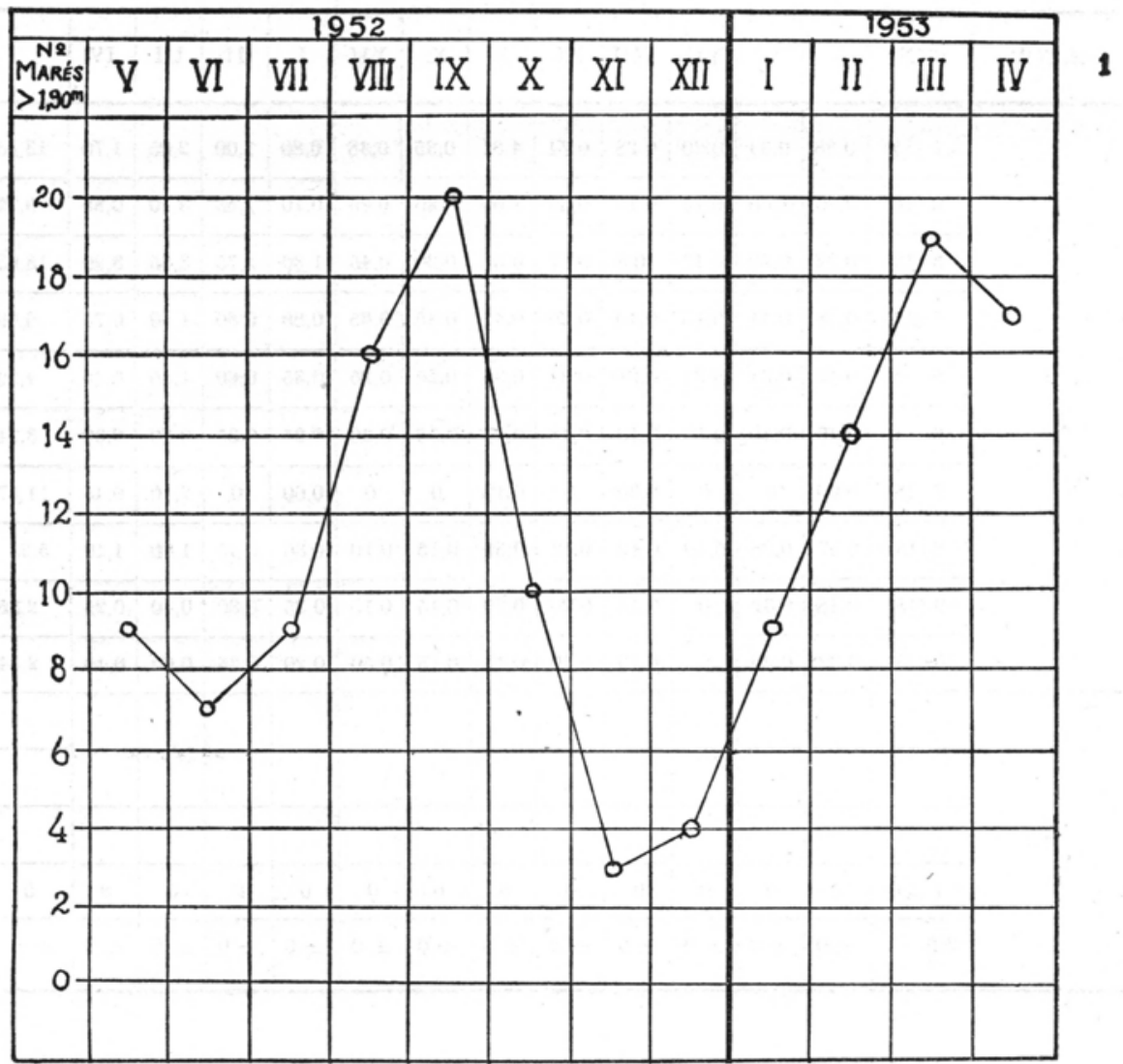




\section{$-208-$ \\ ILHA COMPRIDA}

MARGEM NORTE DA ENTRADA DE CANANÉIA

Modificações observadas na costa calculadas em centímetros

(Setor I-II)

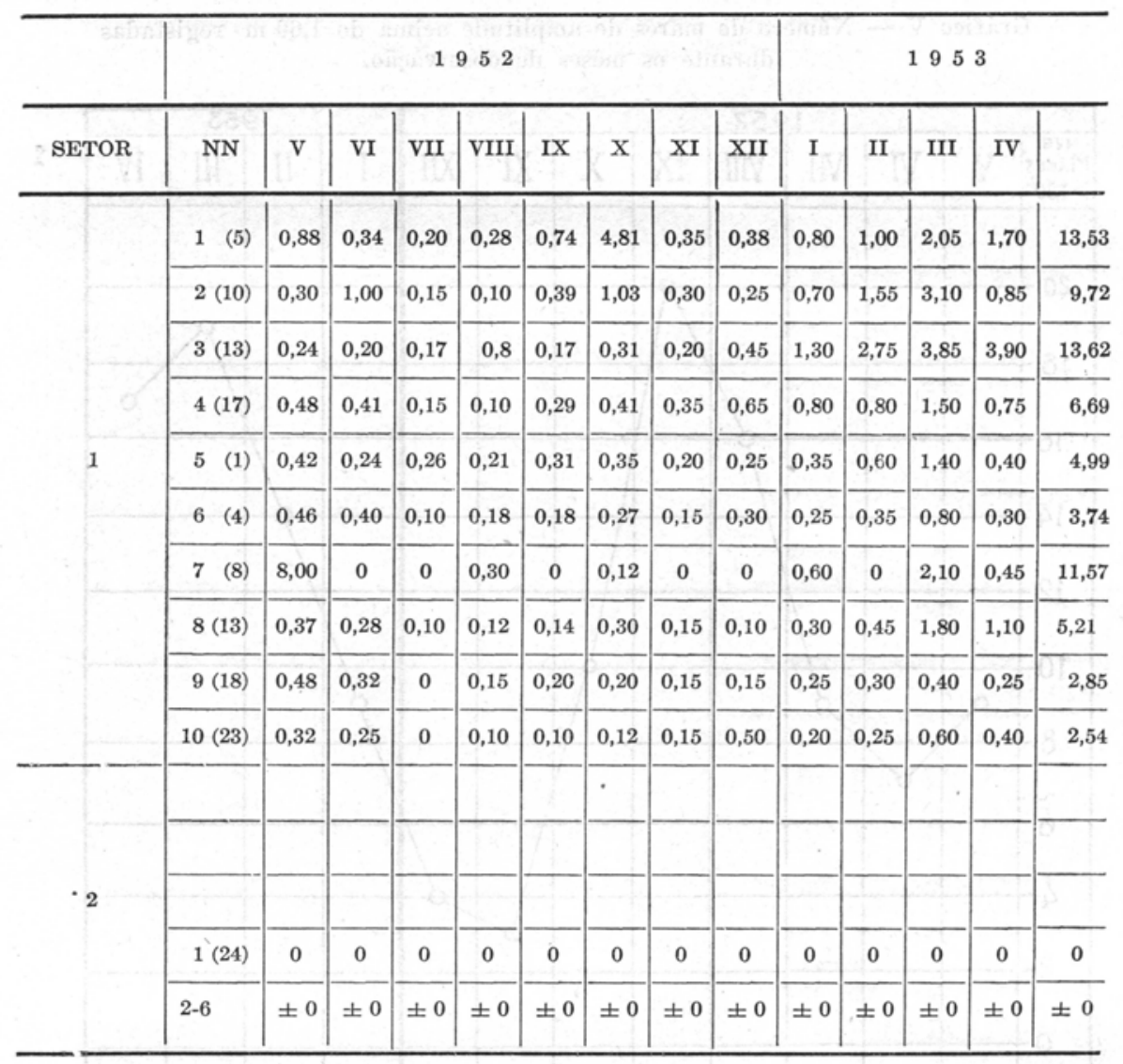




\section{ILHA COMPRIDA}

\section{MARGEM NORTE DA ENTRADA DE CANANEIA}

Modificações observadas na costa calculadas em centímetros

(Setor III-IV)

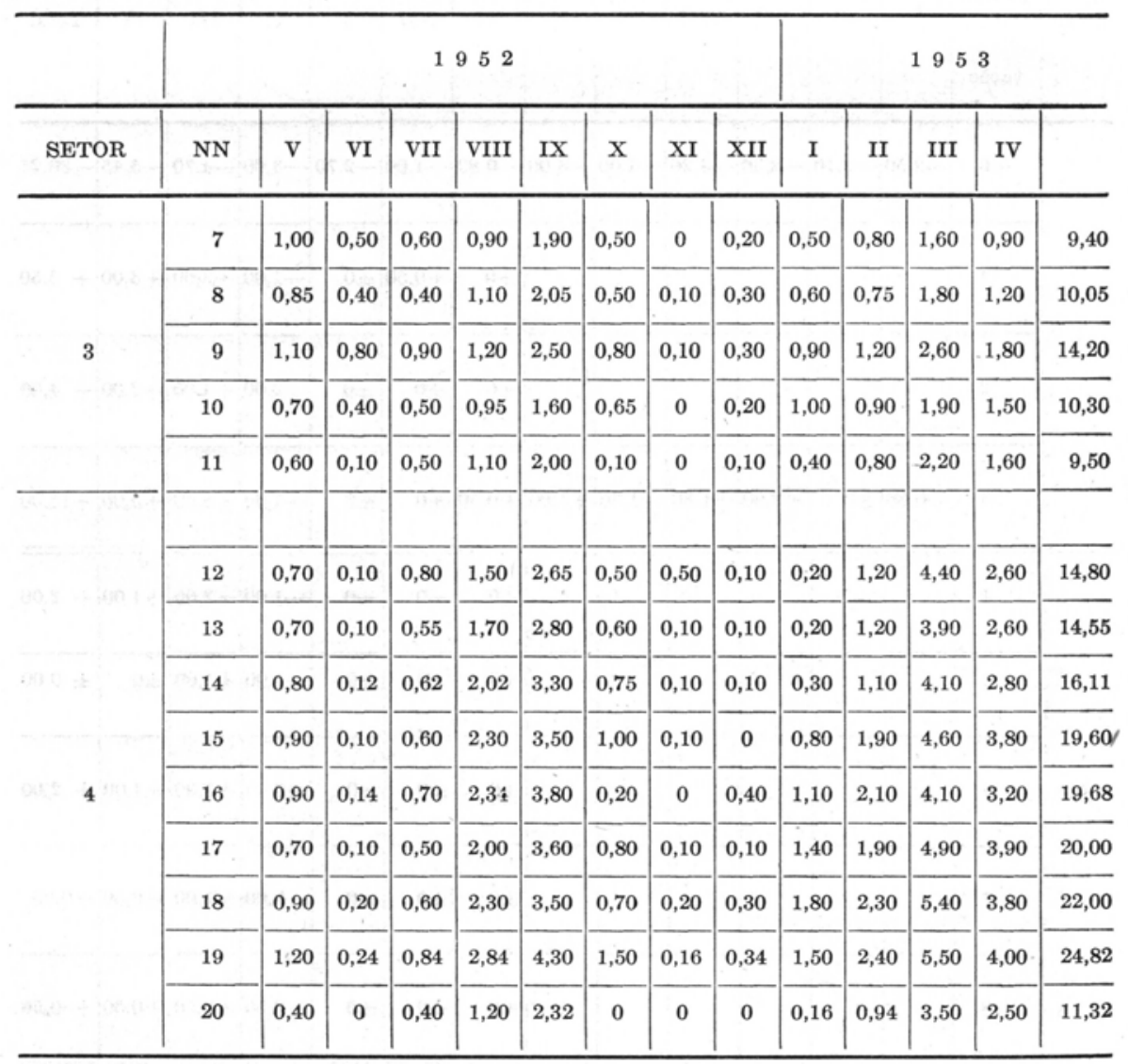


ILHA CARDOSO

MARGEM SUL DA ENTRADA DE CANANÉAA

Modificações observadas na costa calculadas em centímetros

(Setor I-II)

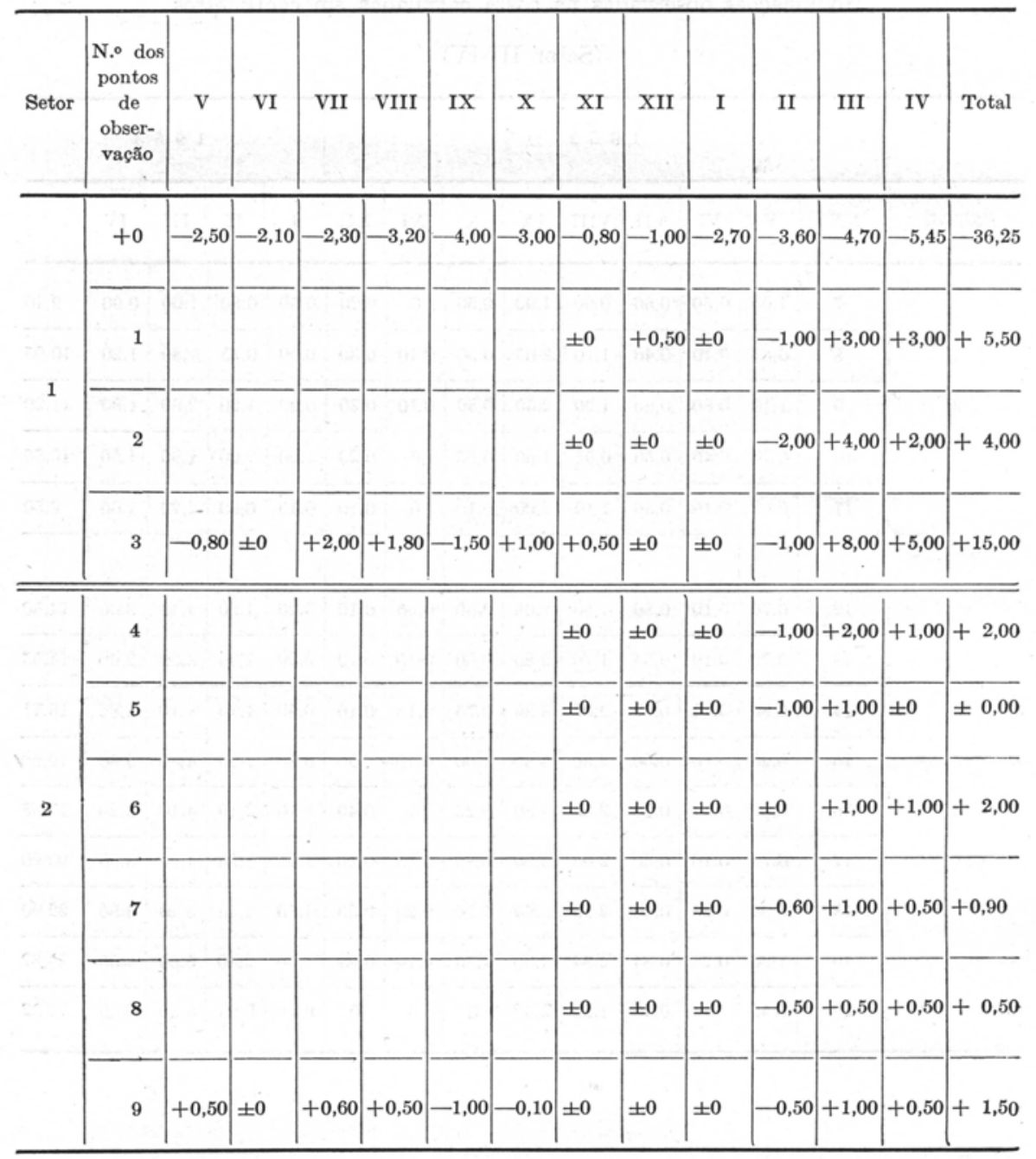


ILHA DO CARDOSO

MARGEM SUL DA ENTRADA DE CANANEIA

Modificações observadas na costa calculadas em centímetros

(Setor III-IV)

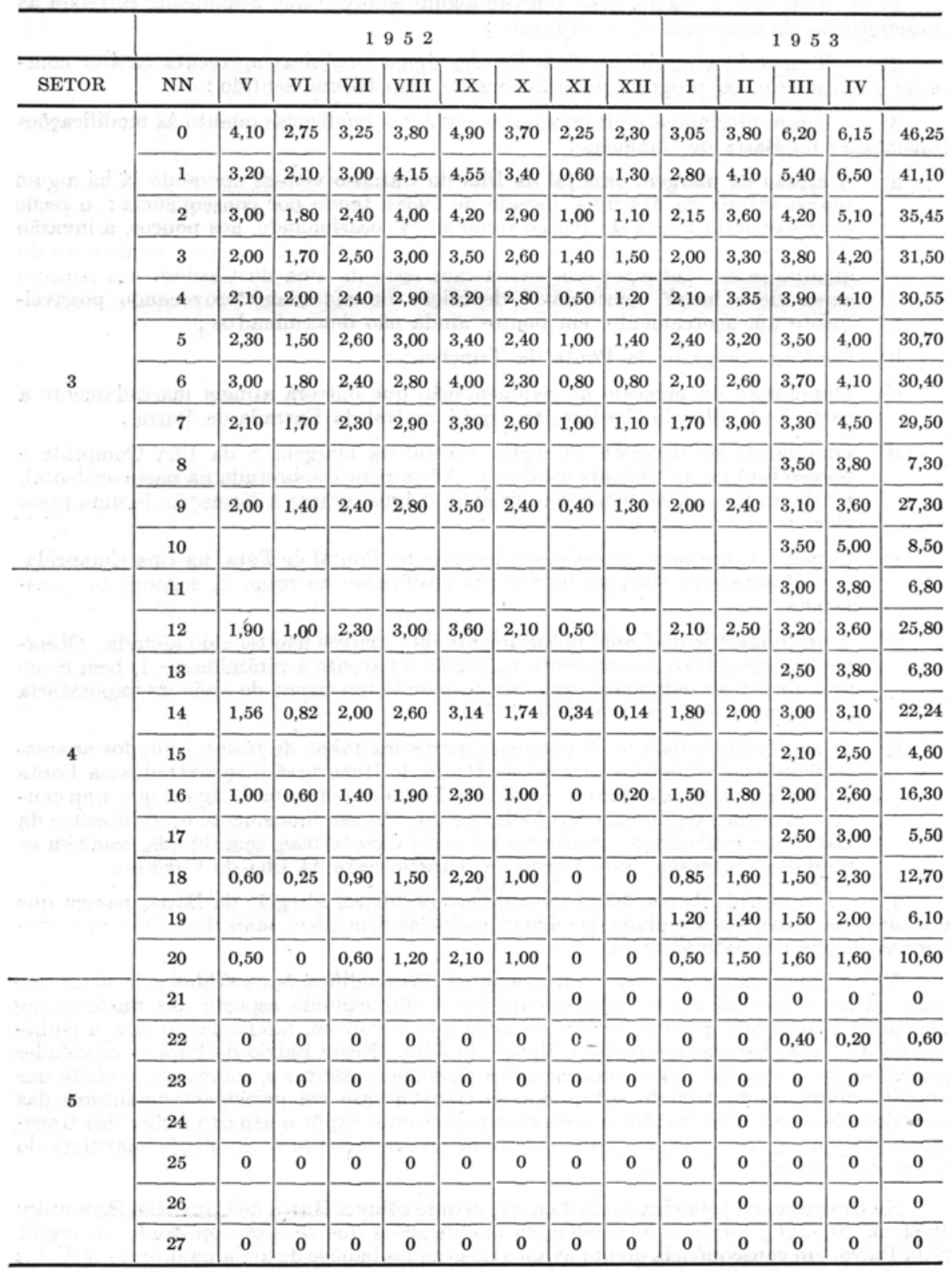




\section{CONCLUSÕES}

Observações efetuadas, durante um ano, na região da Barra de Cananéia permitem, com o auxílio de outros dados colhidos na bibliografia, mapas e informações obtidas da população local, chegar às seguintes conclusões :

1) - Nem tôda a região, mas sòmente alguns setores estão atualmente sofrendo as consequências de uma notável modificação ;

2) - Nem tôda a atividade dinâmica das águas oceânicas apresenta caráter constante e duradouro, ou progride invariàvelmente num mesmo sentido ;

3) - Foram nitidamente observadas as seguintes tendências quanto às modificações constatadas na Barra de Cananéia :

a) A erosão da margem oriental da Ilha do Cardoso vem-se operando já há algum tempo (Mapa da Marinha, datado de 1938), tendo por consequência : o recúo progressivo da Ponta do Perigo rumo ao W, ocasionando, aos poucos, a invasão do mar na parte $\mathrm{S}$ da Ilha Comprida sob o impulso dos ventos dominantes do quadrante S. Tal ação erosiva na face leste da Ilha do Cardoso nos permite supôr deve haver considerável deposição de materiais, provocando possìvelmente um açoreamento, em pontos ainda não determinados ;

b) Contínuo desgaste da Ponta da Trincheira ;

c) Diminuição do processo de sedimentação que outrora atingia marcadamente a costa $\mathrm{N}$ da Ilha do Cardoso, na região central da Entrada da Barra ;

d) Diminuição do desgaste da região central da margem $\mathrm{S}$ da Ilha Comprida e porção interna da Entrada da Barra. Nêsse ponto, sobretudo na parte ocidental, a orla costeira já se distanciou da linha d'água, graças à formação de uma praia elevada ;

e) Começo de um novo processo de desgaste no Pontal de Fóra, na Ilha Comprida, que ùltimamente sofreu uma forte intensificação no rumo $\mathrm{E}$, segundo foi constatado;

f) A profundidade do Canal pròpriamente dito, parece não ter sido afetada. Observou-se apenas um açoreamento na região adjacente à pirâmide $n .^{\circ} 1$, bem como uma formação sedimentar que está formando um banco de areia de importância puramente local, na Ponta do Perigo ;

g) A ocorrência frequente de pequenos seixos marinhos de filitos, oriundos aparentemente das formações xistosas da Ponte de Itacurussá e encontrados na Ponta do Perigo, poderia indicar a existência de um movimento de águas que transportam materiais na direção $N$. Assim sendo, não são ùnicamente os sedimentos da Barra que estão sendo transportados nessa direção mas, sem dúvida, também os produtos da erosão dêste trecho da margem léste da Ilha do Cardoso.

4) - Em virtude de condições topográficas peculiares à região da Barra, parece que a altura das marés e a atividade das águas oceânicas dependem mais de fatores meteorológicos do que dos astronômicos.

5) - Parece muito provável que a maioria das modificações sofridas pela linha costeira ou no relêvo submarino representam em si um segundo aspecto das modificações que estão produzindo grandes bancos de areia que envolvem, num semi-círculo, a embocadura da região lagunar e formam o Baixio de Fóra. Nêsse Baixio de Fóra as atividades conjuntas do vento, das vagas, das correntes marinhas costeiras e, sobretudo, o efeito das grandes marés, estão criando sulcos que se transformam em principais condutores das correntes de maré. Em trabalhos posteriores, pensamos expôr o aspecto cíclico das transformações que alí se operam e que interessam profundamente à circulação marítima do porto de Cananéia.

Na conclusão da primeira parte do nosso estudo sôbre a Barra de Cananéia (Sadowsky 1952 , p. 201-211), foram evidenciadas as modificações que se estão operando na região $\mathrm{S}$ da Barra, em consequência de um avanço de grandes bancos de areia na direção $\mathrm{NW}$ das 
praias da Ilha do Cardoso. Tais bancos formaram depois a chamada "Ilha Nova", cuja parte SW, quase se uniu (maio de 1953) ao "esporão" (Lamego 1946, p. 4) arenoso da Ponta de Itacurussá, movimento que obstruiu quase que totalmente o Canal do Sul. Como resultado disso não sòmente se processa o fechamento do canal habitual da Barra que dá acesso à navegação, como também se modifica o curso típico das correntes de maré.

Continuando os estudos referentes às modificações em curso na Entrada de Cananéia, na Barra e regiões adjacentes, traçamos um programa de investigação futura que obedece às seguintes normas :

1) - Conservação das atuais linhas de observação ;

2) - Instalação de novos pontos de contrôle na Praia de Fóra, da Ilha Comprida, ao $\mathrm{N}$ do marco $\mathrm{n}^{\circ} 20$ (situado fóra do Canal) destinados a seguir os movimentos da areia nas proximidades da costa;

3) - Observações sôbre vagas ;

4) - Após a instalação do marégrafo, serão registadas as alterações ocorridas na praia e nos bancos de areia situados perto da margem ;

5) - Prosseguimento do trabalho de 2 em 2 mêses, afim de se coligirem dados que figurarão em relatórios anuais.

Não queremos terminar este trabalho sem testemunhar nossos sinceros agradecimentos ao Prof. Aziz N. Ab'Sáber pelas suas valiosas sugestões e revisão do manuscrito, e ao nosso colega sr. I. Miniussi pelo auxílio prestado na confecção dos gráficos e desenhos assim como na verificação dos dados topográficos obtidos nos trabalhos de campo.

\section{SUMMARY}

Continuing a series of investigations connected with the shore processes and bar shifting occuring at the entrance of the lagoon region of Cananéia, in the south coast of the State of S. Paulo, the author describes the methods that were used to observe the modifications of the shore line and shoals in the Ilha Comprida and Ilha do Cardoso.

The mechanics of the beach erosion and consequent sedimentary processes are examined in detail and several conclusions are drawn in relation to the apparent periodicity and duration of such phenomena.

The effect of the dynamic activity of ocean waters is considered and the importance of meteorological factors on such activity is emphasized.

In order to continue the work already done a plan for further investigations is presented.

\section{BIBLIOGRAFIA}

Almeida, Antonio Paulino de

1938. Ilha do Bom Abrigo. Rev. do Inst. Hist. e Geogr. de S. Paulo, p. 42-52.

Besnard, W.

1950. Considerações gerais em torno da região lagunar de Cananéia-Iguape. Bol. Inst. Paul. de Oceanografia, Vol. I, n. ${ }^{\circ}$, p. 9-26. S. Paulo.

BOURCART, JACQUES

1952. Les frontières de l'Océan. Paris. 
Johnson, Douglas Wilson

1919. Shore Processes and Shore Line Development. New York.

KroNe, $\mathbf{R}$.

1914. Informações Ethnographicas do Valle do Rio Ribeira de Iguape. Exploração do rio Ribeira de Iguape. Comm. Geogr. e Geolog. do E. de S. Paulo. 2. ed., p. 23-34. S. Paulo.

Lamego, Alberto Ribeiro

1946. O homem e a restinga. Inst. Bras. de Geogr. e Estat., p. 4. Rio de Janeiro.

1946. Restingas na costa do Brasil. Bol. n. ${ }^{\circ} 96$ da Div. de Geol. e Mineralogia.

MARINHA NACIONAL

1939. Mapa de Cananéia - Carta n. 1703. Levantamento efetuado pela Diretoria de Hidrografia e Navegação do Ministério da Marinha. Rio de Janeiro.

RAwitscher, F. K.

1944. Algumas noções sôbre a vegetação do litoral brasileiro. Bol. Assoc. dos Geogr. Bras. n. ${ }^{\circ}$ 5, p. 13-28 (numeração da separata). S. Paulo.

SADOWsKy, V.

1952. Observações sôbre as modificações em curso na entrada de Cananéia, de sua barra e da região adjacente. I - Desgaste das costas. N. $.^{\circ}-$ Ponta da Trincheira (1952). Bol. Inst. Oceanográfico, t. III, fasc. 1 e 2, p. 201-211. S. Paulo.

VIEIRA, J. D. BeLForT

1942. As marés. Porto Alegre. 